\title{
WHOLE BODY VIBRATION ANALYSIS OF BABY HAMMOCK
}

\author{
Ying Hao, Ko ${ }^{1 *}$, Chia Sin, Geh ${ }^{1}$ \\ ${ }^{1}$ Mechanical Engineering Department, School of Engineering and Technology (FOET) \\ Tunku Abdul Rahman University College, \\ *Email: koyh@tarc.edu.my \\ Phone: +60341450123 (Ext: 3544)
}

\begin{abstract}
Studies have been carried on the effect of rocking on a baby and concluded that baby sleeps easier while being rocked. In Malaysia, as in many Southeast Asian Countries, it is common to put babies to sleep in a baby hammock. The vertical rocking motion generated by baby hammock has exposed babies to whole-body vibration (WBV). It has been shown by ISO2631 (1997) that WBV may lead the discomfort and adverse effect on health. Standards have been set by ISO 2631 (1997) concerning the WBV for people in a recumbent position and consider weighted vibrations of more than $2 \mathrm{~m} / \mathrm{s}^{2}$ to be extremely uncomfortable. However, standards concerning the allowable amount vibrations a baby in a baby hammock can safety endure are currently lacking. WBV analysis of the baby hammock with the weight ranged from $3 \mathrm{~kg}$ to $14 \mathrm{~kg}$ is conducted. For each measurement, four conditions are considered: manual rocking, auto rocking with low, medium and high speed. In this study, average root-mean-square values for the acceleration were found to be at a maximum of $2.46 \mathrm{~m} / \mathrm{s}^{2}$, and to be above the extremely uncomfortable level. This study develops a baseline exposure time for the baby hammock before it reaches the safety values of exposure action value (EAV) and exposure limit value (ELV) set by ISO 2631(1997).
\end{abstract}

Keywords: whole body vibration, baby hammock, vibration analysis, human comfort level

\section{INTRODUCTION}

It is very common to put babies into sleep by employing a gentle rocking motion because the rhythmic movement makes the babies felt like they were in the mother's womb ([1]-[3]). Hence, babies felt safe and comfortable while sleeping under the gentle rocking motion [2].

In Malaysia, as in many Southeast Asian Countries, it is common to put babies to sleep in a baby hammock during nap. Traditional baby hammock had been modernized into electric motor controlled baby hammock. Instead of manually rocking the baby hammock, the electric motor provides continuous rocking motion. The vertical rocking motion generated by baby hammock has exposed babies to whole-body vibration (WBV). Babies sleep at baby hammock are exposed to the possible effect from wholebody vibration. One of the effects is excessive vibration will cause negative effect on babies' brain development ([4]-[5]). Whole-body vibration depends on the magnitude, frequency and time of exposure. The longer the time exposure in baby hammock, the 
higher possibility of long-term health effects. Furthermore, high amplitude of the vibration generated by the electric motor controlled baby hammock might bring negative effect to babies' brain development [4]-[5]. According to Suima [6], babies fall asleep easily with gentle rocking at an amplitude of $60 \mathrm{~mm}$ and frequency of $0.55 \mathrm{~Hz}$. This is because $0.55 \mathrm{~Hz}$ is similar to the mother's heart rate $67 \mathrm{bpm}$.

Whole-body vibration measurement has been done on baby car seat and prenatal incubator ([7]-[8]). However, there is no research has been carried out for whole-body vibration on baby hammock. Therefore, whole-body vibration analysis should be done on baby hammock. Babies usually take nap in baby hammock more than in a car seat. Hence, the time exposure of babies in baby hammock is more than the time exposure in car seat and in incubator. There are different range of sleeping time for different age of babies. The average nap time for a new-born baby to 2 years old is in between 2 hours to 9 hours [9].

However, there is no research has been done on whole-body vibration analysis of baby hammock. Hence, this paper aimed to analyse the whole-body vibration analysis of baby hammock based on International Standards Organization (ISO) 2631 [10] standards to evaluate the risk of whole-body vibration of baby hammock.

\section{METHODOLOGY}

\section{Measurement of One-Third Octave Weighted RMS Acceleration}

Figure 1a shows the baby hammock that was chosen to be the example of this project's analysis. It consists of timer and speed controller motor, a set of springs (7 pieces), a hanger and an adapter.

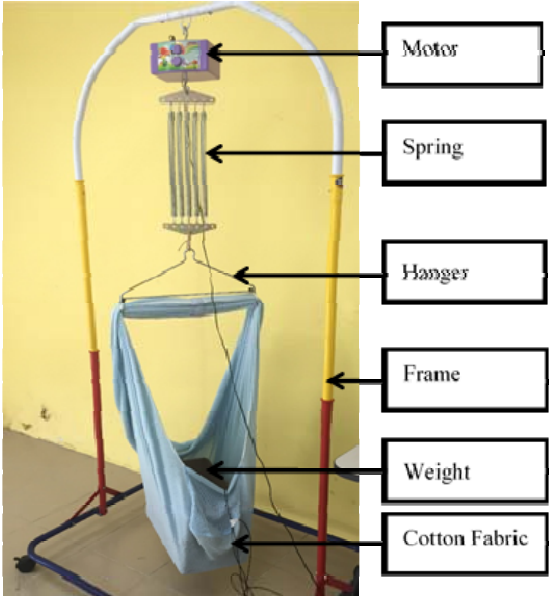

(a)

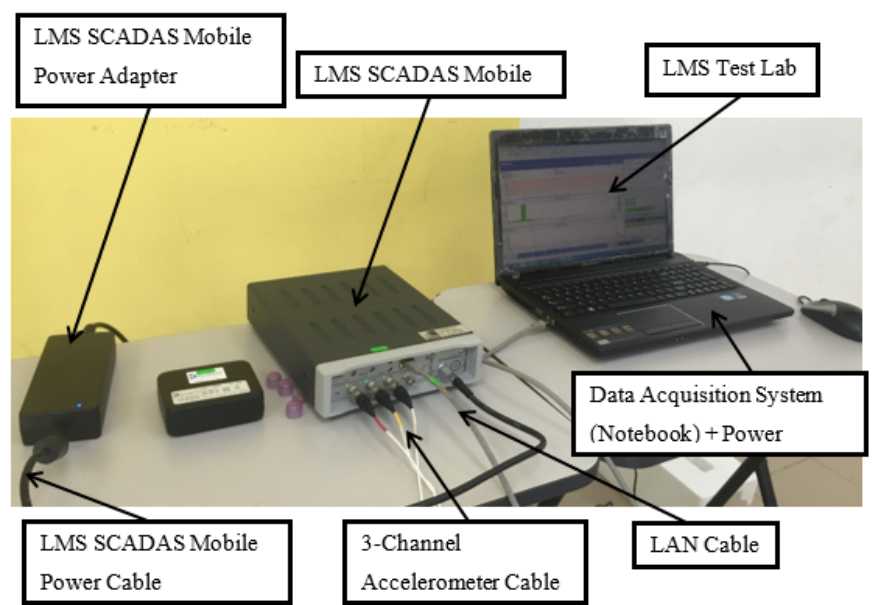

(b)

Figure 1. One-Third Octave weighted RMS acceleration Measurement setup Figure $1 \mathrm{~b}$ shows the devices and software used in this measurement. This includes a triaxis accelerometer (DYTRAN, Type 3263A2), the analyzer (LMS SCADAS Mobile, Siemens) and software (LMS Test Lab). One-third octave frequency analysis were 
carried out in the baby hammock to determine the weighted RMS acceleration based on [10]. Whole-Body Vibration analysis were carried out for two types of rocking which are Automatic rocking and manual rocking. Automatic rocking consists of three different speeds: low, medium and high speed. The baby hammock were carried different loads weight from $3 \mathrm{~kg}$ to $14 \mathrm{~kg}$ to represent the babies' weight from new-born to 2 years old (No baby subject will involve). This is due to measurements were measured using triaxial accelerometer mounted on the weight, the output from the triaxial accelerometer are frequencies and amplitudes, These parameters are sufficient to calculate one-third octave weighted RMS acceleration and estimate the human sensitivity to vibrations for comfort (Table 1). The data obtained from the tri-axes accelerometer were stored and analyzed using LMS Test Lab where x-direction is referred to vertical recumbent direction while $\mathrm{y}$ and $\mathrm{z}$ direction are referred to horizontal recumbent direction. Then, one-third octave frequency analysis in the range of $0.63 \mathrm{~Hz}$ to $160 \mathrm{~Hz}$ were evaluated.

Table 1 : Human Sensitivity to Vibrations for Comfort [10].

\begin{tabular}{ll}
\hline Weighted RMS acceleration & Human sensitivity \\
\hline Less than $0.315 \mathrm{~m} / \mathrm{s}^{2}$ & not uncomfortable \\
$0.315 \mathrm{~m} / \mathrm{s}^{2}$ to $0.63 \mathrm{~m} / \mathrm{s}^{2}$ & a little uncomfortable \\
$0.5 \mathrm{~m} / \mathrm{s}^{2}$ to $1 \mathrm{~m} / \mathrm{s}^{2}$ & fairly uncomfortable \\
$1.25 \mathrm{~m} / \mathrm{s}^{2}$ to $2.5 \mathrm{~m} / \mathrm{s}^{2}$ & very uncomfortable \\
Greater than $2 \mathrm{~m} / \mathrm{s}^{2}$ & extremely uncomfortable \\
\hline
\end{tabular}

\section{Calculation of Overall Weighted RMS Acceleration}

The overall weighted RMS acceleration for three directions: $\mathrm{x}, \mathrm{y}$ and $\mathrm{z}$-direction will calculate as stated in ISO 2631-1 (1997) :

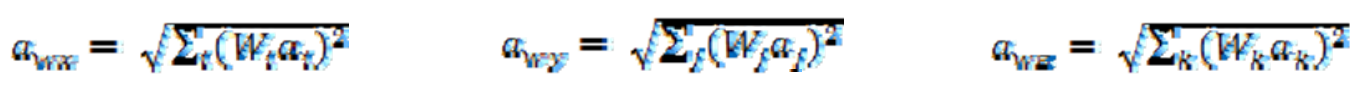

In these equations, the $a_{w x}, a_{w y}$, and $a_{w z}$ represent the overall weighted RMS accelerations at $i^{\text {th }}, j^{\text {th }}$ and $k^{\text {th }}$ frequency for $\mathrm{x}, \mathrm{y}$ and z-direction respectively; whereas $\mathrm{W}_{i}, \mathrm{~W}_{j}$ and $\mathrm{W}_{k}$, are the weighting factors at $i^{\text {th }}, j^{\text {th }}$ and $k^{\text {th }}$ frequency shown in ISO 2631-1, 1997 and $\mathrm{a} i$, $\mathrm{a}_{j}$ and $\mathrm{a} k$ are the RMS acceleration for the $i^{\text {th }}, j^{\text {th }}$ and $k^{\text {th }}$ in $\mathrm{x}, \mathrm{y}$ and z-direction [10]. 


\section{Calculation of Total Vibration Value of Weighted RMS Acceleration}

Total vibration value of weighted RMS acceleration is the combination of overall weighted RMS acceleration in three orthogonal directions: $\mathrm{x}, \mathrm{y}$ and $\mathrm{x}$-direction:

$a_{v}=\sqrt{k_{x}^{2} a_{w}^{2}+k_{y}^{2} a^{2} w_{y}+k^{2} a^{2}{ }_{w z}}$

$a_{v}$ is the total vibration value of weighted RMS acceleration; $a_{w x}, a_{w y}$, and $a_{w z}$ are the weighted RMS accelerations with respect to the orthogonal axes $\mathrm{x}, \mathrm{y}, \mathrm{z}$, respectively and $k_{x}, k_{y}$ and $k_{z}$ are multiplying factors [10]. For a laying human, multiplying factor, $\mathrm{k}$ $=1$ on both horizontal and vertical axes [10].

\section{Calculation of Time to Reach the EAV or ELV}

In order to prevent the long-term health effect or death risk from the vibration transmitted to body, one should need to know the safest exposure time to vibration. Hence, the time needed to reach the exposure action value (EAV) and exposure limit values (ELV) with a given total vibration value of weighted RMS acceleration can be calculated using Equation:

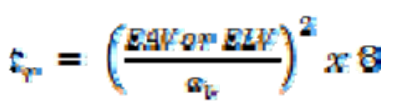

Where $t_{r}$ is the time need to reach the EAV or ELV and $a_{v}$ is the total vibration value of weighted RMS acceleration.

\section{RESULTS AND DISCUSSION}

\section{Total Vibration Value of Weighted RMS Acceleration for Comfort Level}

As can be seen from Table 2, the total vibration values for weights from $3 \mathrm{~kg}$ to $14 \mathrm{~kg}$ subjected to automatic rocking with medium speed, high speed and manual rocking were mostly under the category of very uncomfortable. However, the total vibration values for weights from $3 \mathrm{~kg}$ to $14 \mathrm{~kg}$ subjected to automatic rocking with low speed were considered fairly uncomfortable for babies. And unfortunately, the total vibration value for weight $3 \mathrm{~kg}$ subjected to automatic rocking with high speed is $2.4581 \mathrm{~m} / \mathrm{s}^{2}$ which is extremely uncomfortable to babies. Hence, babies with lower weight is not recommended to use baby hammock subjected to automatic rocking with high speed.

Table 2: Total Vibration Value of Overall Weighted RMS Acceleration.

\begin{tabular}{|l|l|l|l|l|l|}
\hline \multirow{2}{*}{ Springs } & \multirow{2}{*}{$\begin{array}{l}\text { Weight } \\
(\mathrm{kg})\end{array}$} & \multicolumn{2}{|l|}{ Whole-Body Vibration Acceleration $\left(\mathrm{m} / \mathrm{s}^{2}\right)$} & \multirow{2}{*}{ Manual Rocking } \\
\cline { 3 - 5 } & & Automatic Rocking & \\
\cline { 3 - 5 } & & Low Speed & Medium Speed & High Speed & \\
\hline 2 & 3 & 0.9548 & 1.6922 & 2.4581 & 1.5569 \\
\hline
\end{tabular}




\begin{tabular}{|l|l|l|l|l|l|}
3 & 4 & 0.8806 & 1.5775 & 1.8219 & 1.3718 \\
\hline 3 & 5 & 0.8709 & 1.5250 & 1.6902 & 1.1303 \\
\hline 4 & 6 & 0.8871 & 1.3303 & 1.7647 & 1.3036 \\
\hline 4 & 7 & 0.8442 & 1.2307 & 1.5367 & 0.9885 \\
\hline 5 & 8 & 0.7688 & 1.0860 & 1.3930 & 1.3180 \\
\hline 5 & 9 & 0.6546 & 1.0520 & 1.3463 & 1.0805 \\
\hline 6 & 10 & 0.7279 & 1.0520 & 1.0319 & 0.8981 \\
\hline 6 & 11 & 0.7222 & 0.8283 & 0.9780 & 0.6909 \\
\hline 7 & 12 & 0.7038 & 1.3234 & 1.7549 & 1.2507 \\
\hline 7 & 13 & 0.6902 & 1.3013 & 1.5924 & 0.9961 \\
\hline 7 & 14 & 0.5825 & 0.8575 & 1.0365 & 0.9449
\end{tabular}

The data from Table 2 were also used to calculate the time to reach the EAV or ELV using the Equation 3. From Table 3, it is noted that baby hammock is safe to use up to 5 hours 53 minutes for weight $14 \mathrm{~kg}$ subjected to automatic rocking with low speed in order to stay below the EAV. However, it is only limited to 19 minutes for weight $3 \mathrm{~kg}$ subjected to automatic rocking with high speed. Hence, it can be concluded that the heavier the babies, the longer the time needed to reach the EAV and ELV for both types of vertical rocking motion. Therefore, it is recommended that heavier babies are more suitable to use the baby hammock.

Table 3: Time to reach EAV and ELV

\begin{tabular}{|c|c|c|c|c|c|c|c|c|c|c|c|c|c|}
\hline \multirow{4}{*}{ Springs } & \multirow{4}{*}{$\begin{array}{l}\text { Weight } \\
\text { (kg) }\end{array}$} & \multicolumn{12}{|c|}{ Time to Reach EAV and ELV } \\
\hline & & \multicolumn{9}{|c|}{ Automatic Rocking } & \multirow{2}{*}{\multicolumn{3}{|c|}{ Manual Rocking }} \\
\hline & & \multicolumn{3}{|c|}{ Low Speed } & \multicolumn{3}{|c|}{ Medium Speed } & \multicolumn{3}{|c|}{ High Speed } & & & \\
\hline & & $<$ EAV & EAV & ELV & $<$ EAV & EAV & ELV & $<$ EAV & EAV & ELV & $<$ EAV & EAV & ELV \\
\hline 2 & 3 & $\begin{array}{c}2 \mathrm{hr} \\
11 \mathrm{~min}\end{array}$ & $\begin{array}{l}>2 \mathrm{hr} \\
11 \mathrm{~min}\end{array}$ & $\begin{array}{l}>11 \mathrm{hr} \\
36 \mathrm{~min}\end{array}$ & $41 \mathrm{~min}$ & $\begin{array}{l}>41 \\
\min \end{array}$ & $\begin{array}{c}>3 \mathrm{hr} \\
41 \mathrm{~min}\end{array}$ & $19 \mathrm{~min}$ & $>19 \min$ & $\begin{array}{l}>1 \mathrm{hr} \\
45 \mathrm{~min}\end{array}$ & $49 \mathrm{~min}$ & $\begin{array}{l}>49 \\
\min \end{array}$ & $\begin{array}{l}>4 \mathrm{hr} \\
21 \mathrm{~min}\end{array}$ \\
\hline 3 & 4 & $\begin{array}{c}2 \mathrm{hr} \\
34 \mathrm{~min}\end{array}$ & $\begin{array}{l}>2 \mathrm{hr} \\
34 \mathrm{~min}\end{array}$ & $\begin{array}{l}>13 \mathrm{hr} \\
38 \mathrm{~min}\end{array}$ & $48 \mathrm{~min}$ & $\begin{array}{l}>48 \\
\min \end{array}$ & $\begin{array}{l}>4 \mathrm{hr} \\
15 \mathrm{~min}\end{array}$ & $36 \mathrm{~min}$ & $>36 \mathrm{~min}$ & $\begin{array}{l}>3 \mathrm{hr} \\
11 \mathrm{~min}\end{array}$ & $\begin{array}{c}1 \mathrm{hr} \\
03 \mathrm{~min}\end{array}$ & $\begin{array}{l}>1 \mathrm{hr} \\
03 \mathrm{~min}\end{array}$ & $\begin{array}{l}>5 \mathrm{hr} \\
37 \mathrm{~min}\end{array}$ \\
\hline 3 & 5 & $\begin{array}{c}2 \mathrm{hr} \\
38 \mathrm{~min}\end{array}$ & $\begin{array}{l}>2 \mathrm{hr} \\
38 \mathrm{~min}\end{array}$ & $\begin{array}{l}>13 \mathrm{hr} \\
56 \mathrm{~min}\end{array}$ & $51 \mathrm{~min}$ & $\begin{array}{l}>51 \\
\min \end{array}$ & $\begin{array}{l}>4 \mathrm{hr} \\
32 \mathrm{~min}\end{array}$ & $42 \mathrm{~min}$ & $>42 \mathrm{~min}$ & $\begin{array}{l}>3 \mathrm{hr} \\
42 \mathrm{~min}\end{array}$ & $\begin{array}{c}1 \mathrm{hr} \\
33 \mathrm{~min}\end{array}$ & $\begin{array}{l}>1 \mathrm{hr} \\
33 \mathrm{~min}\end{array}$ & $\begin{array}{l}>8 \mathrm{hr} \\
16 \mathrm{~min}\end{array}$ \\
\hline 4 & 6 & $\begin{array}{c}2 \mathrm{hr} \\
32 \mathrm{~min}\end{array}$ & $\begin{array}{l}>2 \mathrm{hr} \\
32 \mathrm{~min}\end{array}$ & $\begin{array}{l}>13 \mathrm{hr} \\
26 \mathrm{~min}\end{array}$ & $\begin{array}{c}1 \mathrm{hr} \\
07 \mathrm{~min}\end{array}$ & $\begin{array}{l}>1 \mathrm{hr} \\
07 \mathrm{~min}\end{array}$ & $\begin{array}{l}>5 \mathrm{hr} \\
58 \mathrm{~min}\end{array}$ & $38 \mathrm{~min}$ & $>38 \mathrm{~min}$ & $\begin{array}{l}>3 \mathrm{hr} \\
23 \mathrm{~min}\end{array}$ & $\begin{array}{c}1 \mathrm{hr} \\
10 \mathrm{~min}\end{array}$ & $\begin{array}{l}>1 \mathrm{hr} \\
10 \mathrm{~min}\end{array}$ & $\begin{array}{l}>6 \mathrm{hr} \\
13 \mathrm{~min}\end{array}$ \\
\hline 4 & 7 & $\begin{array}{c}2 \mathrm{hr} \\
48 \mathrm{~min}\end{array}$ & $\begin{array}{l}>2 \mathrm{hr} \\
48 \mathrm{~min}\end{array}$ & $\begin{array}{l}>14 \mathrm{hr} \\
50 \mathrm{~min}\end{array}$ & $\begin{array}{c}1 \mathrm{hr} \\
19 \mathrm{~min}\end{array}$ & $\begin{array}{l}>1 \mathrm{hr} \\
19 \mathrm{~min}\end{array}$ & $\begin{array}{l}<6 \mathrm{hr} \\
59 \mathrm{~min}\end{array}$ & $50 \mathrm{~min}$ & $>50 \mathrm{~min}$ & $\begin{array}{l}>4 \mathrm{hr} \\
28 \mathrm{~min}\end{array}$ & $\begin{array}{c}2 \mathrm{hr} \\
02 \mathrm{~min}\end{array}$ & $\begin{array}{l}>2 \mathrm{hr} \\
02 \mathrm{~min}\end{array}$ & $\begin{array}{l}>10 \mathrm{hr} \\
49 \mathrm{~min}\end{array}$ \\
\hline 5 & 8 & $\begin{array}{c}3 \mathrm{hr} \\
23 \mathrm{~min}\end{array}$ & $\begin{array}{l}>3 \mathrm{hr} \\
23 \mathrm{~min}\end{array}$ & $\begin{array}{l}>17 \mathrm{hr} \\
54 \mathrm{~min}\end{array}$ & $\begin{array}{c}1 \mathrm{hr} \\
41 \mathrm{~min}\end{array}$ & $\begin{array}{l}>1 \mathrm{hr} \\
41 \mathrm{~min}\end{array}$ & $\begin{array}{l}>8 \mathrm{hr} \\
58 \mathrm{~min}\end{array}$ & $\begin{array}{c}1 \mathrm{hr} \\
01 \mathrm{~min}\end{array}$ & $\begin{array}{l}>1 \mathrm{hr} \\
01 \mathrm{~min}\end{array}$ & $\begin{array}{l}>5 \mathrm{hr} \\
27 \mathrm{~min}\end{array}$ & $\begin{array}{c}1 \mathrm{hr} \\
09 \mathrm{~min}\end{array}$ & $\begin{array}{l}>1 \mathrm{hr} \\
09 \mathrm{~min}\end{array}$ & $\begin{array}{l}>6 \mathrm{hr} \\
05 \mathrm{~min}\end{array}$ \\
\hline 5 & 9 & $\begin{array}{c}4 \mathrm{hr} \\
40 \mathrm{~min}\end{array}$ & $\begin{array}{l}>4 \mathrm{hr} \\
40 \mathrm{~min}\end{array}$ & $>24$ hrs & $\begin{array}{c}1 \mathrm{hr} \\
48 \mathrm{~min}\end{array}$ & $\begin{array}{l}>1 \mathrm{hr} \\
48 \mathrm{~min}\end{array}$ & $\begin{array}{l}>9 \mathrm{hr} \\
33 \mathrm{~min}\end{array}$ & $\begin{array}{c}1 \mathrm{hr} \\
06 \mathrm{~min}\end{array}$ & $\begin{array}{l}>1 \mathrm{hr} \\
06 \mathrm{~min}\end{array}$ & $\begin{array}{l}>4 \mathrm{hr} \\
19 \mathrm{~min}\end{array}$ & $\begin{array}{c}1 \mathrm{hr} \\
42 \mathrm{~min}\end{array}$ & $\begin{array}{l}>1 \mathrm{hr} \\
42 \mathrm{~min}\end{array}$ & $\begin{array}{l}>9 \mathrm{hr} \\
03 \mathrm{~min}\end{array}$ \\
\hline 6 & 10 & $\begin{array}{c}3 \mathrm{hr} \\
46 \mathrm{~min}\end{array}$ & $\begin{array}{l}>3 \mathrm{hr} \\
46 \mathrm{~min}\end{array}$ & $\begin{array}{l}>19 \mathrm{hr} \\
58 \mathrm{~min}\end{array}$ & $\begin{array}{c}1 \mathrm{hr} \\
48 \mathrm{~min}\end{array}$ & $\begin{array}{l}>1 \mathrm{hr} \\
48 \mathrm{~min}\end{array}$ & $\begin{array}{l}>9 \mathrm{hr} \\
33 \mathrm{~min}\end{array}$ & $\begin{array}{c}1 \mathrm{hr} \\
52 \mathrm{~min}\end{array}$ & $\begin{array}{l}>1 \mathrm{hr} \\
52 \mathrm{~min}\end{array}$ & $\begin{array}{l}>9 \mathrm{hr} \\
56 \mathrm{~min}\end{array}$ & $\begin{array}{c}2 \mathrm{hr} \\
28 \mathrm{~min}\end{array}$ & $\begin{array}{l}>2 \mathrm{hr} \\
28 \mathrm{~min}\end{array}$ & $\begin{array}{l}>13 \mathrm{hr} \\
07 \mathrm{~min}\end{array}$ \\
\hline 6 & 11 & $\begin{array}{c}3 \mathrm{hr} \\
50 \mathrm{~min}\end{array}$ & $\begin{array}{c}>3 \mathrm{hr} \\
50 \mathrm{~min}\end{array}$ & $\begin{array}{l}>20 \mathrm{hr} \\
17 \mathrm{~min}\end{array}$ & $\begin{array}{c}2 \mathrm{hr} \\
54 \mathrm{~min}\end{array}$ & $\begin{array}{l}>2 \mathrm{hr} \\
54 \mathrm{~min}\end{array}$ & $\begin{array}{l}>15 \mathrm{hr} \\
25 \mathrm{~min}\end{array}$ & $\begin{array}{c}2 \mathrm{hr} \\
05 \mathrm{~min}\end{array}$ & $\begin{array}{l}>2 \mathrm{hr} \\
05 \mathrm{~min}\end{array}$ & $\begin{array}{l}>11 \mathrm{hr} \\
03 \mathrm{~min}\end{array}$ & $\begin{array}{c}4 \mathrm{hr} \\
11 \mathrm{~min}\end{array}$ & $\begin{array}{l}>4 \mathrm{hr} \\
11 \mathrm{~min}\end{array}$ & $\begin{array}{l}>22 \mathrm{hr} \\
09 \mathrm{~min}\end{array}$ \\
\hline 7 & 12 & $\begin{array}{c}4 \mathrm{hr} \\
02 \mathrm{~min}\end{array}$ & $\begin{array}{l}>4 \mathrm{hr} \\
02 \mathrm{~min}\end{array}$ & $\begin{array}{l}>21 \mathrm{hr} \\
21 \mathrm{~min}\end{array}$ & $\begin{array}{c}1 \mathrm{hr} \\
08 \mathrm{~min}\end{array}$ & $\begin{array}{l}>1 \mathrm{hr} \\
08 \mathrm{~min}\end{array}$ & $\begin{array}{l}>6 \mathrm{hr} \\
02 \mathrm{~min}\end{array}$ & $38 \mathrm{~min}$ & $>38 \min$ & $\begin{array}{l}>3 \mathrm{hr} \\
26 \mathrm{~min}\end{array}$ & $\begin{array}{c}1 \mathrm{hr} \\
16 \mathrm{~min}\end{array}$ & $\begin{array}{l}>1 \mathrm{hr} \\
16 \mathrm{~min}\end{array}$ & $\begin{array}{l}>6 \mathrm{hr} \\
45 \mathrm{~min}\end{array}$ \\
\hline 7 & 13 & $\begin{array}{c}4 \mathrm{hr} \\
11 \mathrm{~min}\end{array}$ & $\begin{array}{l}>4 \mathrm{hr} \\
11 \mathrm{~min}\end{array}$ & $\begin{array}{l}>22 \mathrm{hr} \\
12 \mathrm{~min}\end{array}$ & $\begin{array}{c}1 \mathrm{hr} \\
10 \mathrm{~min}\end{array}$ & $\begin{array}{l}>1 \mathrm{hr} \\
10 \mathrm{~min}\end{array}$ & $\begin{array}{l}>6 \mathrm{hr} \\
14 \mathrm{~min}\end{array}$ & $47 \mathrm{~min}$ & $>47 \mathrm{~min}$ & $\begin{array}{l}>4 \mathrm{hr} \\
10 \mathrm{~min}\end{array}$ & $2 \mathrm{hr}$ & $>2 \mathrm{hr}$ & $\begin{array}{l}>10 \mathrm{hr} \\
39 \mathrm{~min}\end{array}$ \\
\hline 7 & 14 & $\begin{array}{c}5 \mathrm{hr} \\
53 \mathrm{~min}\end{array}$ & $\begin{array}{l}>5 \mathrm{hr} \\
53 \mathrm{~min}\end{array}$ & $>24 \mathrm{hrs}$ & $\begin{array}{c}2 \mathrm{hr} \\
43 \mathrm{~min}\end{array}$ & $\begin{array}{l}>2 \mathrm{hr} \\
43 \mathrm{~min}\end{array}$ & $\begin{array}{l}>14 \mathrm{hr} \\
23 \mathrm{~min}\end{array}$ & $\begin{array}{c}1 \mathrm{hr} \\
51 \mathrm{~min}\end{array}$ & $\begin{array}{l}>1 \mathrm{hr} \\
51 \mathrm{~min}\end{array}$ & $\begin{array}{l}>9 \mathrm{hr} \\
50 \mathrm{~min}\end{array}$ & $\begin{array}{c}2 \mathrm{hr} \\
14 \mathrm{~min}\end{array}$ & $\begin{array}{l}>2 \mathrm{hr} \\
14 \mathrm{~min}\end{array}$ & $\begin{array}{l}>11 \mathrm{hr} \\
50 \mathrm{~min}\end{array}$ \\
\hline
\end{tabular}

\section{CONCLUSION}

Based on the analysis, the comfort level of using the baby hammock based on ISO2631-1 (1997) at different weights ranged from $3 \mathrm{~kg}$ to $14 \mathrm{~kg}$ (represents the babies 
from new-born to 2 years old) had been determined. From the results, the lowest total vibration value is $0.5825 \mathrm{~m} / \mathrm{s}^{2}$ (14 kg subjected to automatic rocking with low speed) which is considered as fairly uncomfortable. While the highest total vibration value is $2.4581 \mathrm{~m} / \mathrm{s}^{2}$ (3 kg subjected automatic rocking with high speed) which is considered as extremely uncomfortable. Furthermore, the time to reach the Exposure Action Value (EAV) and Exposure Limit Value (ELV) had been calculated based on the results from the total vibration values of overall weighted RMS acceleration. From the results, baby hammock is safe to use up to 5 hours 53 minutes for weight $14 \mathrm{~kg}$ subjected to automatic rocking with low speed. However, it is only limited to 19 minutes for weight $3 \mathrm{~kg}$ subjected to automatic rocking with high speed. Hence, it can be concluded that the heavier the babies, the longer the time needed to reach the EAV and ELV for both types of vertical rocking motion. As conclusion, a baseline exposure time for the baby hammock before it reaches its safety values has been developed.

\section{ACKNOWLEDGEMENTS}

The authors would like to acknowledge Tunku Abdul Rahman University College for the laboratory facilities and technical support for this project.

\section{REFERENCES}

[1] Pederson, D. R., Champagne, L. \& Pederson, L. L. (1969). Relative Soothing Effects of Vertical and Horizontal Rocking. ERIC Number: ED046504.

[2] Bayer, L., Constantinescu, I., Perrig, S., Vienne, J., Vidal, P. P., Mühlethaler, M. \& Schwartz, S. (2011). Rocking synchronizes brain waves during a short nap. Current Biology, 21(12), R461-R462.

[3] Barnard, K. E. (1972). The effect of stimulation on the duration and amount of sleep and wakefulness in the premature infant. PhD Thesis, University of Washington.

[4] Lu, C. H., Luo, C. H., Chen, Y. J., \& Yeh, T. F. (1997). An automatic swinging instrument for better neonatal growing environment. Review of scientific instruments, 68(8), 3192-3196.

[5] Bang, S., Lam, R. \& LoCicero, N. (2011). Rock Me Baby: The Automatic Baby Rocker. Project for San Jose State University, Department of Mechanical and Aerospace Engineering.

[6] Suima (2009). Suima: The Japanese Robocrib of the Future/Past. (http://daddytypes.com/2009/02/03/suima_the_japanese_robocrib_of_the_future past.php). Accesssed on 2 January 2015

[7] Nilsson, M. (2005). Health risk aspects and comfort for infants in infant seats for cars (VTI notat). Linköping: VTI., VTI notat 24-2005. Retrieved from http://urn.kb.se/resolve?urn=urn:nbn:se:vti:diva-1546 
[8] Giacomin, J., Gallo, S. 2003. In-vehicle Vibration Study of Child Safety Seats. Ergonomics, 2003, vol 46, no 15, 1500-1512

[9] Denise Fields and Ari Brown, MD. 2008. National Sleep Foundation, Baby 411 and Toddler 411.

[10] ISO 2631-1:1997, Mechanical vibration and shock - Evaluation of human exposure to whole-body vibration - Part 1: General requirements. 